\title{
Current Status and Key Trends in Agricultural Land Holding and Distribution in Punjab, Pakistan: Implications for Food Security
}

\author{
Asad Naseer \\ Institute of Agricultural and Resource Economics, University of Agriculture, Faisalabad, \\ Pakistan \\ Muhamamd Ashfaq \\ Institute of Agricultural and Resource Economics, University of Agriculture, Faisalabad, \\ Pakistan \\ Muhammad Abid
}

Research Group Climate Change and Security, Institute of Geography, University of Hamburg, Grindelberg 7, 20144 Hamburg, Germany

Amar Razzaq

Institute of Agricultural and Resource Economics, University of Agriculture, Faisalabad, Pakistan \&

Punjab Economic Research Institute, Lahore, Government of Punjab, Pakistan

Sarfraz Hassan

Institute of Agricultural and Resource Economics, University of Agriculture, Faisalabad, Pakistan

Received: June 29, 2016 Accepted: July 18, 2016 Published: September 11, 2016

doi:10.5296/jas.v4i4. $9670 \quad$ URL: http://dx.doi.org/10.5296/jas.v4i4.9670

\begin{abstract}
The economy of Pakistan is mainly dependent on agriculture which is mainly owned by small farm householders. The rapidly increasing population and stagnant agricultural growth coupled with other economic issues are threatening food security and livelihood of rural population in Pakistan. The main objective of the study was to appraise the change in the agrarian structure in Punjab province and to see the current status and key trends in land holing and distribution. It is done by reviewing of the overtime structural changes in land
\end{abstract}


holdings using inter-census data of 1960-2010 t enabled the present analyses to depict a clear picture of the overtime changes that had come about in the agrarian structure of Punjab. The magnitude of shifts from one period to the other was calculated with the help of Lorenz ratio and Gini coefficient. The study showed disparities in ownership and distribution of land holdings in Punjab. The findings suggested a decrease in inequality in land distribution through effective land reform and distribution. This will help to increase farm income of small-scale and subsistence farming communities to cater for the threatening issues of food insecurity.

Keywords: Pakistan, Punjab, Gini Coefficient, Lorenz Ratio, Land inequality, Food Security

\section{Introduction}

Poverty in Pakistan is widespread with more than $40 \%$ of the population mainly in the rural areas fall under the poverty line of $\$ 1.25$ a day (HDR, 2013). Urban population in Pakistan is connected to the rural sector in terms of dependence on rural farming for food and dairy products (Begum and Yasmeen 2011). Hence, to sustain food security and well-being both in rural and urban areas, improvement in the agricultural productivity and agricultural systems is a key.

Land, a key foundation in agricultural system, plays an important role in sustaining rural livelihoods and food security in the developing world (Koirala et al., 2016). The allocation of land holdings may also determine the exploitation of farm assets and use of modern technology and may be used as an indicator to determine the pace of development of the region (Singh and Kahlon, 1977). Rapid population growth, widespread poverty, stagnant agricultural growth, extreme climate-related events have put pressure on existing land tenure and distributions patterns in Pakistan. The literature showed a strong inter-relationship between rural poverty, agricultural performance and land distribution in many of the developing countries (IFAD, 2011; Moreda, 2012; Sabates-Wheeler, 2005; Zulfiqar et al., 2016). In addition, other factors that may be responsible for low and stagnant agricultural growth in developing countries like Pakistan may include inefficient use of production resources such as water, labor and capital; lack of technology and access to institutional services such as credit, extension and marketing information (Sattar, 2012; GOP, 2015).

The land distribution and tenure system in Pakistan is highly unequal and biased towards landlords and large farmers. According to the World Bank report, only $2 \%$ of the farm households control $45 \%$, while $98 \%$ of the households control only $55 \%$ of total agricultural land (Nagayets, 2005; Khan et al., 2013). This unequal distribution of land is one of the major reasons of rural poverty in Pakistan that restrict small farmers' access to improved services (MacDonald et el., 2013). Studies also show that recent economic and agricultural developments mainly focused large farmers and ignored small farmers (Lipton, 2006). That may be the reason that farmers in Pakistan are only able to achieve only one-third of potential crop yields in Pakistan (Hussain, 2005). In order sustain the agricultural growth and local food security, the performance of small land holders needs to be improved (Thapa and Gaiha, 2011). 
Considering the need for development of Pakistan, land ownership and development of rural agricultural land cannot be ignored (Rashid and Sheikh, 2014). Studies show significant relationship between land ownership and the agricultural productivity and farm income (Deininger, 2004; Hirshima, 2008; Vasquez et al., .2002; Guiling et al., 2009; Cavailhès and Wavresky, 2003; Peterson, 1984 and 1986). There is knowledge gap on overtime trends of land distribution and structural changes in Pakistan. This is because previous studies mainly focused on the short term relationship of land and agricultural productivity (Chaudhary 1990; Chaudhary et al., 1980; Khan et al., 2013). Hence, in order to design effective agricultural development policies, there is a dire need of such study that investigates the current structure of land its distribution and tenure systems in Pakistan. The findings of such studies could be used as basis to provide substantial support needed for small landholders in the context of new scenario of land changes.

Keeping in view the knowledge gap, the present study analyzes the overtime change of land holdings in Punjab province, Pakistan in terms of size, number, and pattern of ownership. Specifically this study examines overtime structural changes in the number of farms, land tenure settings and average size of land holdings and also aimed at measuring the extent of equality in the ownership and distribution of land holding in Punjab, Pakistan

\section{Methodology}

\subsection{Study Area Description}

This study was done in the Punjab province, which is the most populous and second largest province in Pakistan in terms of land area (Abid et al., 2016). Despite its dry climate, extensive irrigation makes it a rich agricultural region and a leading economic tier in the national economy (Abid et al., 2015; Badar et al., 2007). Overall, the province accounts for $56 \%$ of the total cultivated area and more than half of the total agricultural gross domestic product (GOP, 2014). Total reported area in the province for agricultural activities is 18 million hectares out of which only 13 million hectares is cultivated.

Empirical modeling

In this study, we categorize farms into three groups based on GOP (2014): small farms with land holding less than 5 acres ( 2 hectares); medium farmers with land holdings between 5 to 25 acres (or 2-5 ha) and large farmers with land holdings above than 25 acres (5 ha).

Following the former studies (Ahmad et al., 2003; Jayne et al., 2003; Qureshi et al., 2004), Lorenz curve technique was used to test the degree of overtime structural changes in land distribution in Pakistan. The magnitude of Lorenz curve shows the degree of shifts from one period to the other (Theil, 1967). Lorenz curve is a graph depicting the variance of size distribution of land from perfect equality. This curve depicts the relationship between total number of farms and total farm area (Chaudhary et al., 1980). The Lorenz curve and Gini-coefficient may be represented by following equations (Edwards, 1980; Chatta and Singh, 1992):

$$
\text { Lorenz Ratio }=1-\sum_{i=1}^{n} \frac{\left(X_{i}-X_{i-1}\right)\left(Y_{i}-Y_{i-1}\right)}{10,000}
$$




$$
\text { Gini Coefficient }=\frac{\sum_{i=1}^{n=1} X_{i+1} Y_{i}}{\sum_{i=1}^{n=1} X_{i} Y_{i+1}}
$$

Where, $X_{i}=$ cumulative percentage frequency with respect to number of farms corresponding to the size of class $\left(X_{i}=1,2,3, \ldots, \mathrm{n}\right), Y_{i}=$ cumulative percentage frequency with respect to farm area corresponding to size of class $\left(\mathrm{Y}_{\mathrm{i}}=1,2,3, \ldots, \mathrm{n}\right), X_{i+1}$ and $Y_{i+1}=$ preceding observation of $X_{i}$ and $Y_{i}, X_{i+1}$ and $\mathrm{Y}_{\mathrm{i}+1}=$ previous observation of $X_{i}$ and $Y_{i}$.

Lorenz Curves at various points of time showed the actual quantitative relationship between percentage of farm numbers and Farm area. The more the Lorenz Curve is away, from the perfect equality diagonal line, the greater is the degree of inequality. If the values of Lorenz Ratio and Gini Coefficient are close to one it means higher inequality and if these values are close to zero it means higher equality (Ferreira and Ravallion, 2009).

\section{Results and discussion}

\subsection{Current tenure and size structure in Pakistan}

In Pakistan, land tenure system generally is not conducive to progress farming as cultivators has to give a lion's share of the produce to the landlords. The pattern of land tenure-ship determines the operational status of farming community. The pattern of land occupancy in Pakistan and Punjab in 2010 is shown in Table 1. From the results, it is evident that the distribution of land gave rise to massive self-cultivation as more than 80 percent in Pakistan and also in Punjab is self-cultivated by owners and owner cum tenants while less than 30 percent of farm land in Pakistan and Punjab is cultivated by tenants and owner cum tenants.

Table 1. Number of Farms and Farm Area by Tenure in Punjab and Pakistan

\begin{tabular}{|c|c|c|c|c|c|c|c|c|}
\hline Units & \multicolumn{4}{|c|}{ Number of Farms (Millions) } & \multicolumn{4}{|c|}{ Farm Area (Million Acres) } \\
\hline Classification & Total & $\begin{array}{c}\text { Owner } \\
\text { Operators }\end{array}$ & $\begin{array}{l}\text { Owner } \\
\text { cum } \\
\text { Tenants }\end{array}$ & Tenants & Total & $\begin{array}{l}\text { Owner } \\
\text { Operators }\end{array}$ & $\begin{array}{l}\text { Owner } \\
\text { cum } \\
\text { Tenants }\end{array}$ & Tenants \\
\hline Pakistan & 8.26 & 6.74 & 0.60 & 0.92 & 52.91 & 39.43 & 7.58 & 5.89 \\
\hline Percentage & 100 & 81.6 & 7.26 & 11.14 & 100 & 74.5 & 14.3 & 11.2 \\
\hline Punjab & 5.25 & 4.32 & 0.45 & 0.48 & 29.32 & 20.60 & 5.37 & 3.35 \\
\hline Percentage & 100 & 82.28 & 8.57 & 9.15 & 100 & 70.26 & 18.31 & 11.43 \\
\hline
\end{tabular}

Source: Pakistan Census of Agriculture, 2012

The distribution of ownership of land is one of the important factor of agricultural productivity and economic well-being of farmer community and is also affect their social and political status in society. Like all other developing agricultural countries of the world, the distribution of agriculture land is highly skewed. It is evident from the Table 2, that land distribution in Pakistan is highly skewed in favor of large farm sizes, top 4 percent farmers owns 40 percent of farms while the bottom 90 percent owned less than 44 percent of farms. Corresponding figures for the Punjab shows that only top 2.4 percent farmers owns more 24 
percent of farms while the bottom 91.9 percent owns 58.2 percent of farms. Wide spread poverty and inequitable distribution of farm services and resource to a great extent is the result of such skewed distribution of farm land. The main challenge of development in Pakistan lies in rural sector which suffer from wide spread poverty and a number of social, economic and technological problems. The social problems mainly arise from skewed distribution pattern of land ownership which makes the rural society both rigid and iniquitous.

Table 2: Number of farms and farm area by size in Punjab and Pakistan

\begin{tabular}{|l|c|c|c|c|c|c|c|c|}
\hline \multicolumn{1}{|c|}{ Units } & \multicolumn{4}{|c|}{ Number of Farms (Millions) } & \multicolumn{4}{c|}{ Farm Area (Million Acres) } \\
\hline Classification & Total & Small & Medium & Large & Total & Small & Medium & Large \\
\hline Pakistan & 8.35 & 7.52 & 0.50 & 0.33 & 55.59 & 24.35 & 8.54 & 22.7 \\
\hline Percentage & 100 & 90 & 6 & 4 & 100 & 43.8 & 15.36 & 40.84 \\
\hline Punjab & 5.45 & 5.01 & 0.31 & 0.13 & 28.77 & 16.75 & 5.07 & 6.95 \\
\hline Percentage & 100 & 91.9 & 5.7 & 2.4 & 100 & 58.2 & 17.6 & 24.2 \\
\hline
\end{tabular}

Source: Pakistan Census of Agriculture, 2012

\subsection{Trend in number of farms by size of land holdings}

Large farms remained fairly constant from 1960 to 2010, but medium farms were fairly constant up till 1990 then decrease thereafter while small farms decreased initially from 1960 to 1962 then increased over the remaining period from about 0.60 of a million to about 4.70 million (Figure 1). The main reason for the increase small lands could be attributed to traditional distribution of lands among family successors. On the other hand, a decrease in small farms from 1960 to 1970 could be attributed to the fear that land reforms could cause loss of lands to land lords which made them took back their lands from tenants or sharecroppers. Another reason could be the impact on green revolution through the introduction of modern technologies such as tube wells and tractors on local land distribution systems (Chaudhry et al., 1980). These innovations may attract landlords to cultivate lands on their own with less use of labor and sharecropping. Furthermore, medium farms showed no change during the period 1960-1990 and then a sudden decline afterwards in 2000. Here, we can see 1990 a turning point for both small (showing sudden increasing trend) and medium scale farms (showing a sudden declining trend). This shows an overtime ladder process involving amalgamation of medium farms into small farms during 1990-2010 which may be due to intergenerational land passing customs in rural areas. 


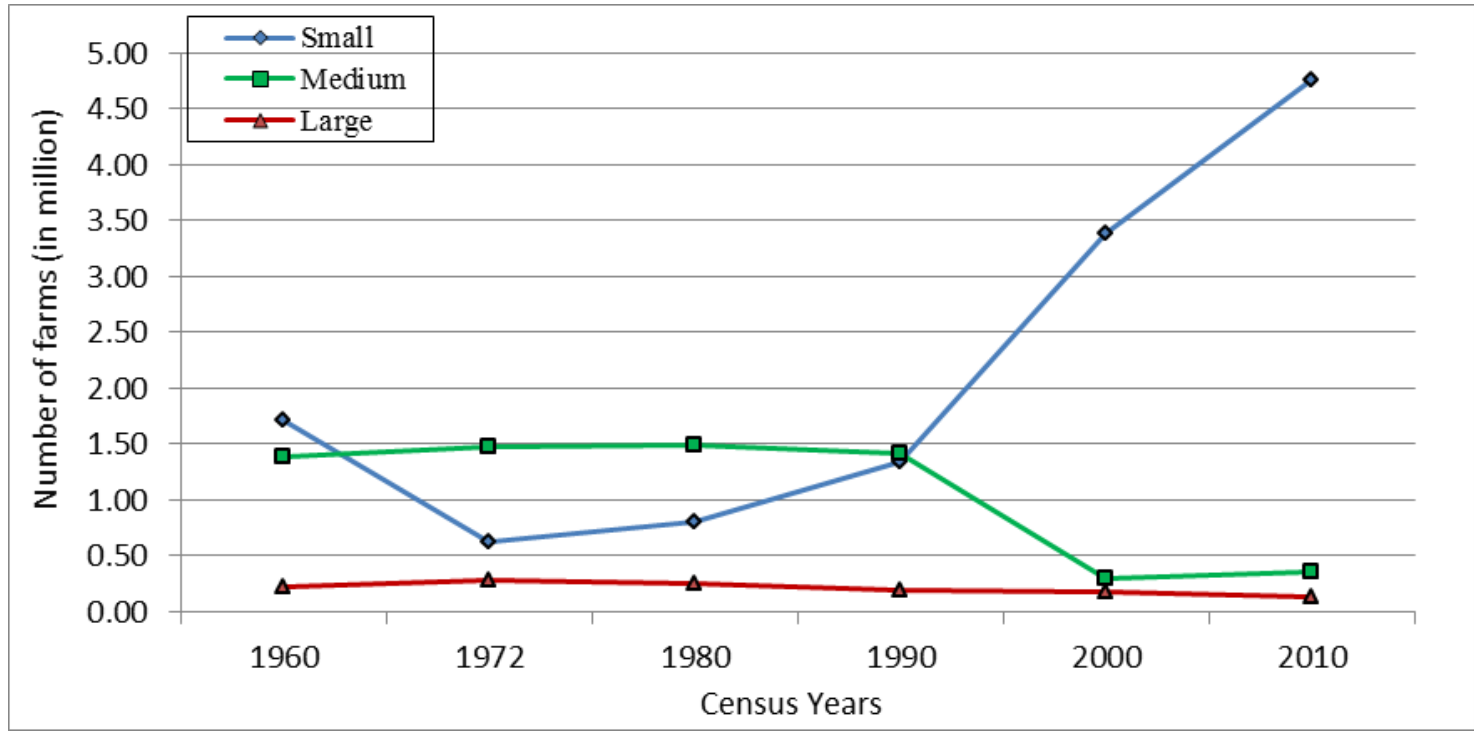

Figure 1. Trend in number of farms by farm size (in millions) from 1960 to 2010

\subsection{Trend in Number of Farms by Tenure}

The pattern of changes in the tenancy status is shown in Figure 2. There was a decline in owner-cultivators from 1960 to 1972 and a sudden increasing trend in owner-cultivators from 1972 to 2010. However, owner-cum-tenant shows a sharp decline from 1960 to 1972 followed by almost no changing pattern from 1972 to 2010. Tenant category of farmers showed an increase trend between 1960 and 1972 and a slight declining trend from 1972 to 2010. Overall, owner-cultivators account for a major share among all tenure settings. An increasing trend in owner-cultivators may be due to the division of land among ancestors. These findings are in agreement with the findings of other studies (e.g. Singh and Kahlon 1976; Mahmood 2000).

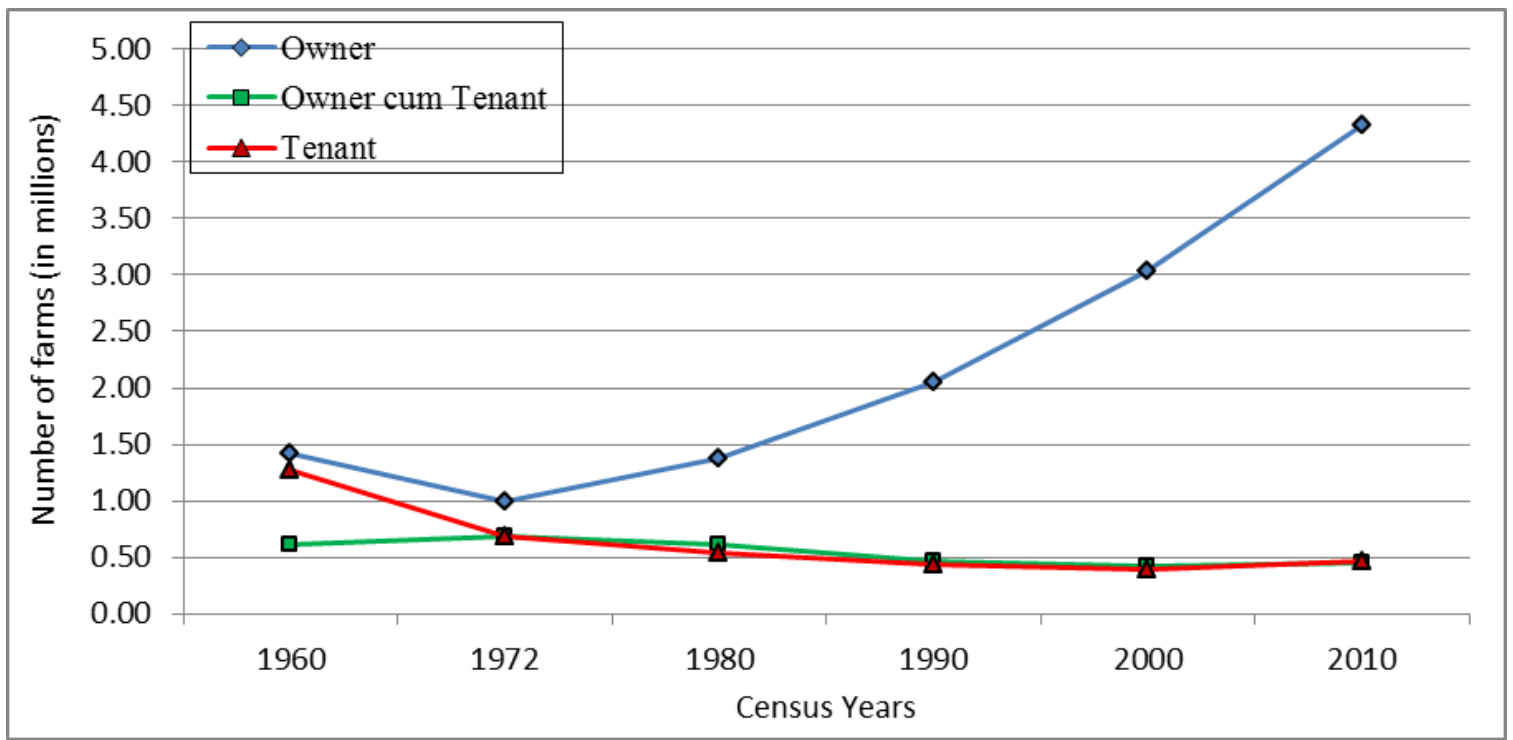

Figure 2. Trend in number of farms by tenure (in millions) from 1960 to 2010

Further we analyzed the overtime trend by combing farm size and tenure categories (Figure 
3). All empirical findings of this study show that besides overtime changing trend of inequality land distribution for the period 1960-2010, there was no significant improvement in size distribution of agriculture holdings in Punjab. From policy point of view, removing inequality in land distribution is a critical issue in Punjab agriculture. Small farmers which were $90 \%$ in numbers occupied $40 \%$ of land area, whereas the remaining $60 \%$ of the area is occupied by medium $(6 \%)$ and large $(4 \%)$ farmers.

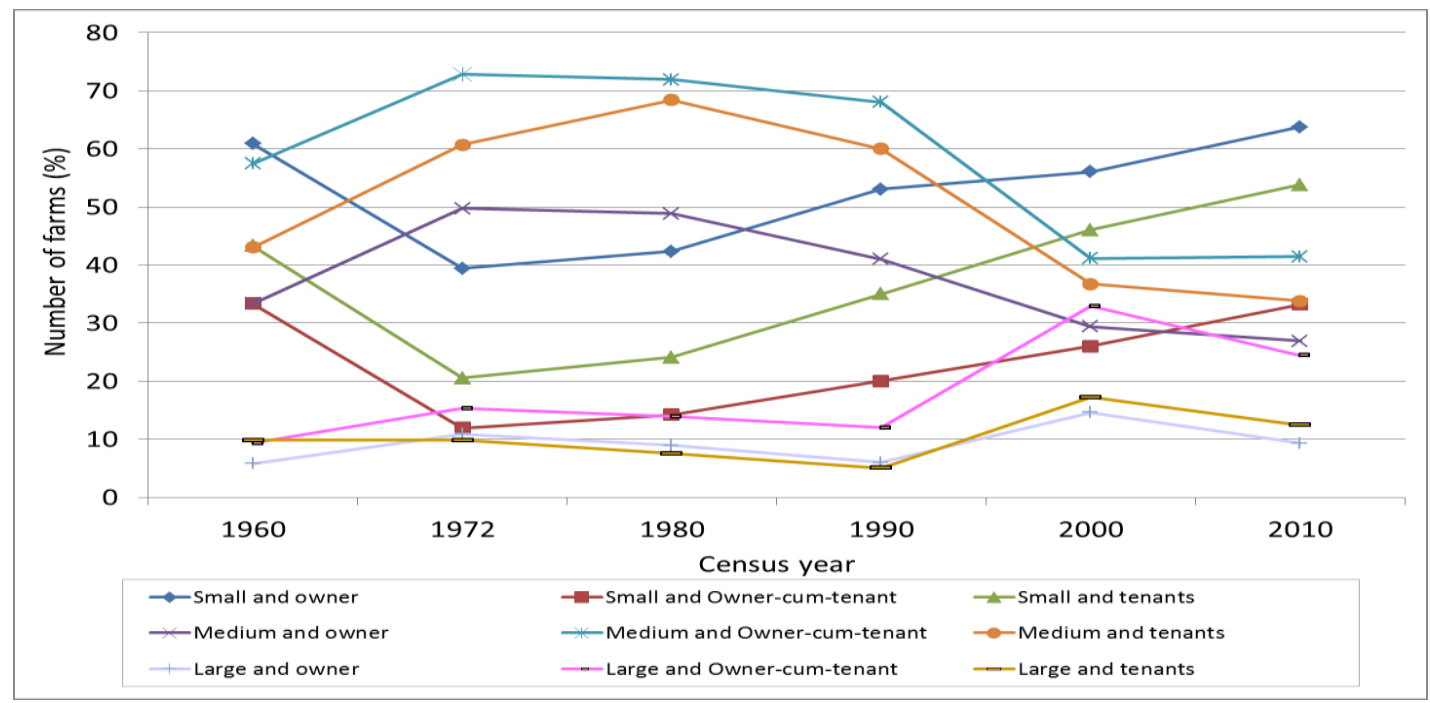

Figure 3. Trend in Percentage distribution of farms by tenure and size

\subsection{Changes in average farm size}

After some increase in average farm size from 1960 to 1972, a decreasing trend in average farm size can be observed (Figure 4). The increasing trends in 1960s may be due to the positive aspects of land reforms which may have benefited the small land holders. Average farm size declined from 8.78 acres in 1960 s to 5.6 acres in 2010 . This may be attributed to opposite trends of increase in owners and small farms.

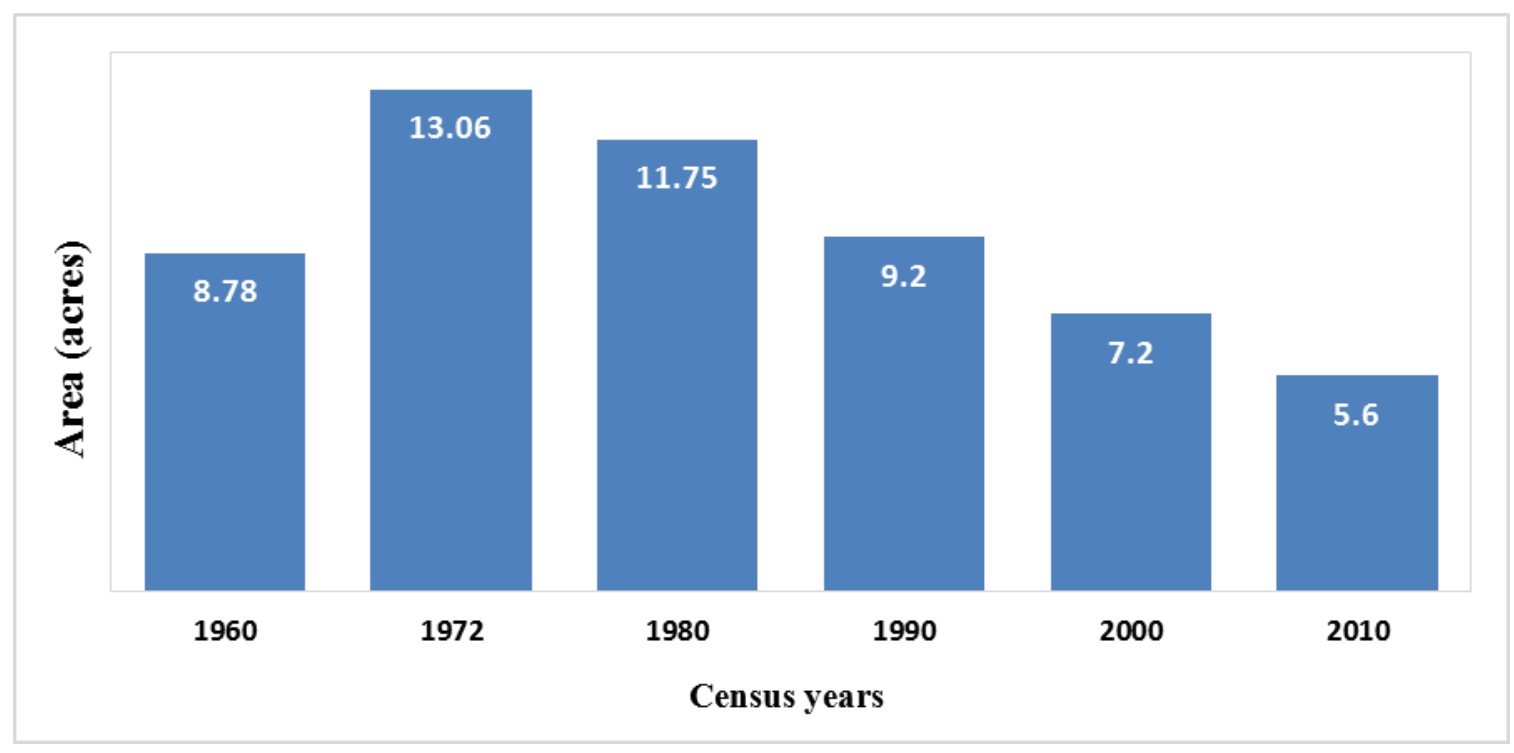

Figure 4. Changes in Average Farm Size Since 1960 (10 years interval) 


\subsection{Size Distribution of Total Land Holding}

All farms were arranged in ascending order and total area is divided into distinct size groups. We divided the entire farmer population into successive quintiles (5 groups) according to ascending farm sizes in order to determine the skewness in the size distribution of total land holdings. Table 3 describes the size distribution of operational farm area in the province of Punjab in quintiles. There was highly unequal distribution of operational holdings as a high percentage of farms operated a very small proportion of farm area while a very minute number of operators held a large proportion of area. But over the period trend was towards equitable distribution of operational area.

Table 3. Percentage distribution of total farms and total farm areas in quintiles

\begin{tabular}{|c|c|c|c|c|c|c|}
\hline $\begin{array}{c}\text { Census } \\
\text { year }\end{array}$ & $\begin{array}{l}\text { Farm size } \\
\text { (acres) }\end{array}$ & $\begin{array}{c}0-< \\
5\end{array}$ & $\begin{array}{l}5-< \\
12.5\end{array}$ & $\begin{array}{c}12.5-< \\
25\end{array}$ & $\begin{array}{c}25-< \\
50\end{array}$ & $>50$ \\
\hline \multirow{2}{*}{1960} & $\begin{array}{l}\% \text { No. of } \\
\text { farms }\end{array}$ & 50.7 & 27.8 & 14.7 & 5.4 & 1.4 \\
\hline & $\%$ Farm area & 10.9 & 25 & 28.5 & 20 & 15.6 \\
\hline \multirow{2}{*}{1972} & $\begin{array}{l}\% \text { No. of } \\
\text { farms }\end{array}$ & 26.1 & 39 & 23.1 & 8.8 & 3 \\
\hline & $\%$ Farm area & 4.8 & 24.6 & 28.8 & 21.3 & 20.5 \\
\hline \multirow{2}{*}{1980} & $\begin{array}{l}\% \text { No. of } \\
\text { farms }\end{array}$ & 31.6 & 39.2 & 19.4 & 7.2 & 2.6 \\
\hline & $\%$ Farm area & 6.5 & 26.3 & 27.2 & 19.3 & 20.7 \\
\hline \multirow{2}{*}{1990} & $\begin{array}{c}\% \text { No. of } \\
\text { farms }\end{array}$ & 45 & 34 & 14 & 5 & 2 \\
\hline & $\%$ Farm area & 11 & 29 & 24 & 17 & 19 \\
\hline \multirow{2}{*}{2000} & $\begin{array}{l}\% \text { No. of } \\
\text { farms }\end{array}$ & 56 & 29 & 10 & 4 & 1 \\
\hline & $\%$ Farm area & 16 & 31 & 22 & 17 & 14 \\
\hline \multirow{2}{*}{2010} & $\begin{array}{l}\% \text { No. of } \\
\text { farms }\end{array}$ & 63.8 & 26.72 & 7 & 1.84 & 0.64 \\
\hline & $\%$ Farm area & 22 & 36 & 20 & 10 & 12 \\
\hline
\end{tabular}

Source: Author's own Calculation

\subsection{Empirical findings of Lorenz curve and Gini-coefficient}

The extent and character of inequality and skewness in the land distribution was calculated by establishing the relationship between total number of farms and total farm area in the province of Punjab. The size distribution of land is a measure, most commonly used by economists and it means that the distribution of land according to class size.. It deals with 


\section{Ml Macrothink}

individual class and the area commanded by them. Skewness in the land distribution can be determined by the criteria that a distribution will be highly skewed when top 20 percent of total farm population receives more than half of the total land. While inequality in land distribution, determined with the help of Lorenz ratio and Gini Coefficient. The higher the value of coefficient, the higher the inequality of land distribution and lower it is the more equitable the distribution of land.

The Lorenz curve created from the land distribution data from all six census years is shown in Figure 5. The distribution of Lorenz curve shows a high level of inequality in the distribution of land holdings overtime among the land holders as the Lorenz curve stuck very near to each other in all census years. This agrees with the results of Vyas (1974), Dahiya (1976) Hassan et al., (2001), Ahmad et al., (2003) who concluded that structure of land holding showed a trend equitable distribution.

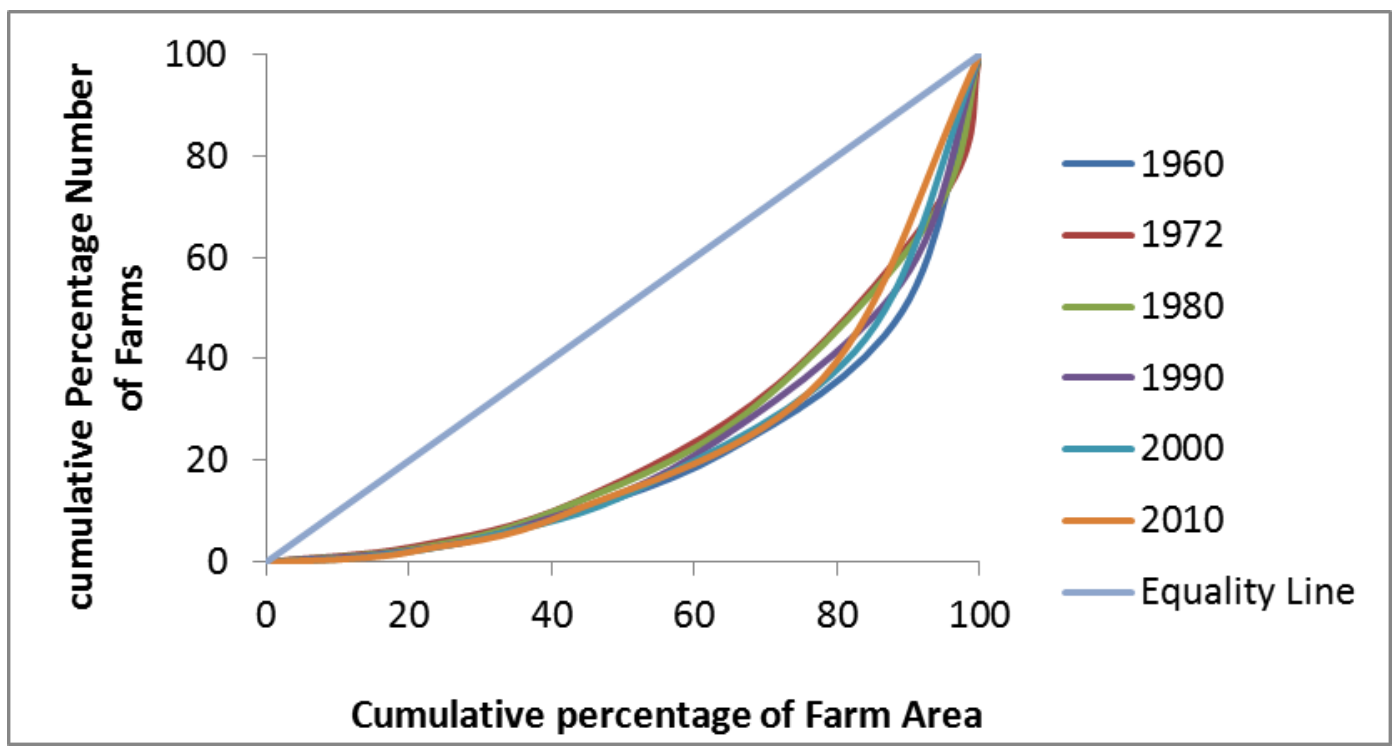

Figure 5. Lorenz Curve for all census versus showing inequality

The other ways to find out the extent of inequality prevailing in the distribution of land holding is the Lorenz ratio. Lorenz ratios calculated for total land holdings of the province for each census year are shown in Table 4. The ratio declined from 0.82 in 1960 to 0.75 in 2010. But a very high value of this ratio indicates that the extent of inequality is very high. Gini Coefficient is another short and more convenient measure of inequality. This is an aggregate numerical measure of inequality ranging from zero (perfect equality) to one (perfect inequality). The higher the value of coefficient indicated higher inequality of land distribution.

Table 4. Gini Coefficient and Lorenz ratio of total land holdings (1960-2010)

\begin{tabular}{lllllll}
\hline Census Year & 1960 & 1972 & 1980 & 1990 & 2000 & 2010 \\
\hline Gini-Coefficient & 0.566 & 0.772 & 0.732 & 0.618 & 0.529 & 0.468 \\
Lorenz Ratio & 0.820 & 0.803 & 0.804 & 0.806 & 0.790 & 0.747 \\
\hline
\end{tabular}


Source: Author's own calculations

The values of Gini Coefficient are just the explanation of overtime movement of Lorenz Curves which showed that inequality in the distribution of total land holdings slightly decreased overtime. The highest values of Gini Coefficient were 0.772 and 0.732 in 1972 and 1980, respectively. This was the result of sharp decrease in number of farms from 3.32 million to 2.37 million in 1972 than in 1960 due to the fear of land reforms and the introduction of new technologies mainly tractor and tube well. The land lords got rid of tenants and started self-cultivation. For self-cultivation, they need additional labor and tractor proved handy to replace labor. Availability of tractor, tube-well, improved seed and fertilizer were in short supply, large farmers due to their influence and financial power availed the lion's share of these inputs and reap benefits thereof. Small farmers were bypassed and went into oblivions as efficient producer. These developments continued unchecked as a result number and area of small farmers in 1980 were reduced by $52 \%$ and $39 \%$, respectively than in 1960. About 800 thousand farmers left agriculture during this period (Chaudhary and Hassan, 1990; Khan et al 2008). But the high value of this coefficient showed a highly unequal distribution of total land holdings. The above facts indicate that distribution of total land holdings was not only highly skewed (in favor of large farmers) but also highly unequal in the province of the Punjab.

\subsection{Resource Use Pattern}

It was also found that equitable distribution of land holdings affect the utilization of farm resources and adoption of modern technology and ultimately determine the pace of development of agriculture and thus, the economy. Resource use pattern (cropping intensity, land use intensity, labor use, and adult animals units per acre of small, medium and large farmers, small farmers) performed much better in term of these indicators. Land use intensity of small, medium and large farmers was $98 \%, 94.5 \%$ and $89 \%$, respectively. Similarly, cropping intensity of small, medium and large farmers were $184 \%, 169 \%$ and $162 \%$. Family and permanent hired labor per acre of small, medium and large farmers were1.89, 0.67 , and 0.15 while adult animal units per acre on small medium and large farms were 1.50 , 0.96 and 0.19 , respectively (GOP, 2012).

\section{Conclusion}

This study reveals that the land distribution in Pakistan is highly inequitable and skewed in favor of large farmers but on the other hand the small farmers are utilizing farm resource more efficiently than the large farmers. There is need to redistribute agricultural land to minimize the extent of inequality and skewness by taking land from the large holders and handing it to the small farmers. But the point arises how we can minimize the inequality at other's cost as distribution of agricultural land is Pareto optimal. Equitable distribution of land holdings can be achieved through governmental legislation and intervention through implementing effective land reforms system for equitable distribution of land resources. Such efforts may not only empower small farmers but will also enhance their living standard and overall agricultural productivity. Further, equitable land allocation leads towards accelerated economic growth and to achieve targets of eradicating poverty and sustaining food security at local and regional level. 


\section{Macrothink}

Journal of Agricultural Studies

ISSN 2166-0379

201 Vol. 4, No. 4

\section{Acknowledgments}

The authors would like to acknowledge the Census of Agriculture organization, Pakistan Bureau of Statistics and the Institute of Agricultural and Resource Economics, University of Agriculture Faisalabad, Pakistan.

\section{References}

Abid, M., Scheffran, J., Schneider, U. A., \& Ashfaq, M. (2015). Farmers' perceptions of and adaptation strategies to climate change and their determinants: the case of Punjab province, Pakistan. Earth Syst. Dyn., 6, 225-243.

Abid, M., Schilling J., Scheffran J., \& Zulfiqar F. (2015) Climate change vulnerability, adaptation and risk perceptions at farm level in Punjab, Pakistan. Sci Total Environ 547:447-460. doi:10.1016/j.scitotenv.2015.11.125.

Adams, \& Richard, H. (2002). Nonfarm Income, Inequality, and Land in Rural Egypt Economic Development and Cultural Change, 50(2), 339-363.

Ahmad, M., S. Hassan, \& Chaudhry, M. A. (2003). An Economic Appraisal of Structural Changes in Land Holdings in North Western Frontier Province (NWFP) of Pakistan, 736(540.17), 666-8.

Akram, L., \& Haroon, A. (2008). (Re) imagining Agrarian Relations? The World Development Report 2008: Agriculture for Development. Development and Change, 39(6), 1145-1161.

Badar, H., Ghafoor, A., \& Adil, S. A. (2007). Factors affecting agricultural production of Punjab (Pakistan). Pakistan Journal of Agricultural Sciences, 44, 3.

Begum, R., \& Yasmeen, G. (2011). Contribution of Pakistani women in agriculture: productivity and constraints. Sarhad J. Agric, 27(4), 637-643.

Chatta, I. S., \& J. Singh. (1992). Farm size distribution and land tenurial pattern in India. Journal of Rural Reconstruction, 25(1), 53-62. Dept. Of Economics and Sociology, Punjab Agri. Univ. Ludhiana, India.

Chaudhary, M. A., \& Sarfraz, H. (1990). Need and scope for economic revival of small farmers. Proceedings of the national seminar on economic revival of small farmers (March 4-5 1989), University of Agriculture Faisalabad, 11-26, 1990.

Chaudhry, M. G. (1990). Land agglomeration under changing technology: some inferences from Pakistan. Pakistan Development Review, 29, 111-122.

Chaudhary, M. A., Mustafa, U., \& Muhammad, F. (1980). Distribution of land and production efficiency. Pakistan agriculture, 3(5), 20-23.

Dahiya, L. N. (1976). Changes in structural distribution of land ownership and land use in India. Indian J. of Agri. Econ., 31(3), 47.

Deininger, K. (2004). Land policies for growth and poverty reduction: key issues and 
challenges ahead. Inter-Regional Special Forum on the Building of Land Information Policies in the Americas, Aguascalientes, Mexico.

Edwards, C. J. W. (1980). The effects of changing size upon level of farm fragmentation: A Somerest case study. J. of Agri. Econ., 29(2), 144-54. New Uni. Of Ulster, U. K.

Ferreira, F., \& Ravallion, M. (2009). Poverty and inequality: The global context, 599-636.

GOP, (2012). Pakistan bureau of statistics, Government of Pakistan, Islamabad, available at http://www.pbs.gov.pk/

GOP, (2014). Economic survey of Pakistan Finance division, Economic advisor's wing, Government of Pakistan, Islamabad.

GOP, (2015). Census of Agriculture Publication, 1960 to 2010. Federal Bureau of Statistics, Government of Pakistan, Islamabad. http://www.pbs.gov.pk/content/agriculture-census-wing (different issues).

GOP, (2015). Agriculture, Economic survey of Pakistan Finance division, Economic advisor's wing, Government of Pakistan, Islamabad.

Govt. of Punjab, (2012). Punjab Development Statistics (various issues). Bureau of Statistics. Govt. of Punjab, Lahore, Pakistan. http://www.bos.gop.pk/?q=publicationreports

Gras, C. (2009). Changing patterns in family farming: the case of the Pampa Region, Argentina. Journal of Agrarian Change, 9(3), 345-364.

Guiling, P. B., Wade, B., \& Damona, D.(2009). Effect of urban proximity on agricultural land values. Land Economics, 85(2) 252-264.

Hassan, S., A., Khan, A., Zahid, M., \& Hassan, I. (2001). An economic appraisal of structural changes in land holdings in Punjab, Pakistan Journal of applied sciences, 1(2), 163-165.

HDR, (2013). Human Development Report UNDP. http://hdr.undp.org/en/2013-report

Hirashima, S. (2008). The land Market in Development: a case Study of Punjab in Pakistan and India. Economic and Political Weekly: 41-47.

Hussain, A. (2005). Agriculture growth and poverty reduction: A policy perspective. In international seminar on management of the Pakistan economy, Lahore School of Economics, Pakistan.

IFAD (International Fund for Agricultural Development), (2011). Rural poverty report 2010.

Jayne, T. S., Yamano, T., Weber, M. T., Tschirley, D., Benfica, R., Chapoto, A., \& Zulu, B. (2003). Smallholder income and land distribution in Africa: implications for poverty reduction strategies. Food policy, 28(3), 253-275.

Khan, F. Z., Sagheer, M., Hasan, M., Tahira, H., Hassan, F., Amir, S., \& Wahid, A. (2013). Agricultural Dynamics in Pakistan: Current Issues and Solutions. Russ. J. Agric Socio-Economic Sci. 20(8). 


\section{$\triangle$ Macrothink}

Journal of Agricultural Studies

ISSN 2166-0379

201 Vol. 4, No. 4

Khan, M. M., Zhang, J., \& Hashmi, M. S. (2008). Land distribution, technological changes and productivity in Pakistan's agriculture: some explanations and policy options. School of Economics, Huazhong University of Science and Technology, Wuhan, 430074, P.R.China.

Koirala, K. H., Mishra, A., \& Mohanty, S. (2016). Impact of land ownership on productivity and efficiency of rice farmers: The case of the Philippines. Land Use Policy, 50, 371-378.

Lipton, M. (2006). "Can Small Farmers Survive, Prosper, or be the Key Channel to cut Mass Poverty", Journal of Agricultural and Development Economics, 3(1), 58-85.

MacDonald, J. M., Korb, P., \& Hoppe, R. A., (2013). Farm size and the organization of US crop farming. US Department of Agriculture, Economic Research Service.

Mahmood, H. Z. (2000). An estimation of overtime changes in size distribution and ownership pattern of agriculture holdings in the province of Punjab. M. Sc. Thesis, Deptt of Agri Econ., Uni. of Agri. Faisalabad, Pakistan.

Moreda, T. (2012). Linking vulnerability, land and livelihoods: Literature review.Sample chapter. International Institute of Social Studies. The Hague.

Nagayets, O. (2005). Small farms: current status and key trends. The future of small farms, 355 .

Nazli, H., Haider, H. S., \& Tariq, A. (2012). Supply and demand for cereals in Pakistan, 2010-2030.

Peterson, W. L. (1984). Land Quality and Prices. University of Minnesota. Institute of Agriculture, Forestry and Home Economics. Staff Paper, 84-29.

Peterson, W. L. (1986). Land Quality and Prices. American Journal of Agricultural Economics, 68, 812-819.

Qureshi, M. G., Qureshi, S. K., \& Salam, A. (2004). "Impact of Changing Profile of Rural Land Market in Pakistan on Resource Allocation and Equity [with Comments]." The Pakistan Development Review, 43(4), 471-492.

Rashid, S., \& Sheikh, A. T. (2015). Farmers' Perceptions of Agricultural Land Values in Rural Pakistan. Presented at annual Pakistan Society of Development Economics conference in Islamabad on $05-30-2015$. http://alturl.com/i8vbo

Sabates-Wheeler, R. (2005). Asset Inequality and Agricultural Growth: How are patterns of asset inequality established and reproduced?

Sattar, T. (2012). A Sociological Analysis of Constraining Factors of Development in Agriculture Sector of Pakistan. Journal of Economics and Sustainable Development, 3(8), 8-24.

Singh, A., \& Kahlon, S. S. (1977). The impacts of new technology on farm size, tenure relations and land rents in the Punjab: Indian J. Agri. Econ., 31-36.

Thapa, G., \& Gaiha, R. (2011). "Smallholder farming in Asia and the Pacific: Challenges and 


\section{Macrothink}

Journal of Agricultural Studies

ISSN 2166-0379 201 Vol. 4, No. 4

Opportunities", paper presented at the Conference on new directions for small holder agriculture, 24-25 January 2011, Rome, IFAD

Theil, H. (1967). Economics and information theory Amsterdam: North Holland.

Vasquez, O., Wright, K. S., Nelson, J. R., \& Hamilton, J. R. (2002). Determining the effects of land characteristics on farmland values in south-central Idaho. Paper presented at AAEA WAEA Annual Meeting in Long Beach, CA. University of Idaho. Department of Agricultural Economics and Rural Sociology. Research Series No. 02-05:1-18.

Vyas, V. S. (1974). Structural changes in small farm sector. Economic and Political Weekly. 11(2), 15-19.

Zulfiqar, F., Ullah, R., Abid, M., \& Hussain, A. (2016). Cotton production under risk: a simultaneous adoption of risk coping tools. Natural Hazards, 1-16. http://dx.doi.org/10.1007/s11069-016-2468-9.

\section{Copyright Disclaimer}

Copyright for this article is retained by the author(s), with first publication rights granted to the journal.

This is an open-access article distributed under the terms and conditions of the Creative Commons Attribution license (http://creativecommons.org/licenses/by/3.0/). 